\title{
Performance of the $\mathrm{T}$ cell senescence markers in predicting
}

\section{the active disease of systemic lupus erythematosus [version 1;}

\section{peer review: 1 approved, 1 approved with reservations, 1 not}

\section{approved]}

\author{
Kusworini Handono1, Mirza Zaka Pratama (D2), Radiyati Umi Partan³, \\ Hani Susianti (D1, Nimas Eka Firdaningrum44, Siti Roziah Ria Famuji4, \\ Ade Wildan Rizky Fachry ${ }^{4}$, Norma Hanifah Sumarta4, Handono Kalim² \\ ${ }^{1}$ Department of Clinical Pathology, Faculty of Medicine Universitas Brawijaya - Saiful Anwar General Hospital, Malang, East Java, \\ 65112, Indonesia \\ ${ }^{2}$ Rheumatology Division Department of Internal Medicine, Faculty of Medicine Universitas Brawijaya - Saiful Anwar General Hospital, \\ Malang, East Java, 65112, Indonesia \\ ${ }^{3}$ Department of Internal Medicine, Faculty of Medicine Sriwijaya University, Palembang, South Sumatera, 30662, Indonesia \\ ${ }^{4}$ Department of Biomedical Science, Faculty of Medicine, Universitas Brawijaya, Malang, 65112, Indonesia
}

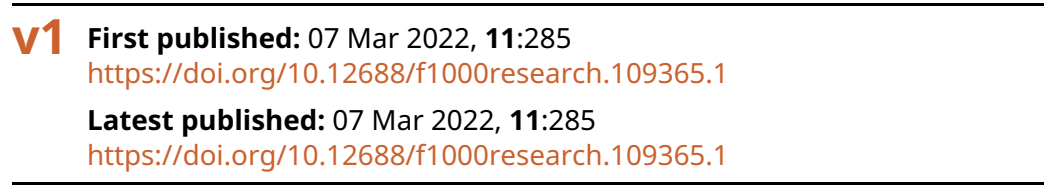

\section{Abstract}

Background: Accelerated immunosenescence has been observed in several autoimmune diseases, including systemic lupus erythematosus (SLE). T cell senescence plays an essential role in the destruction of organs in SLE patients. This study aimed to identify the ability of immunosenescence markers to predict SLE disease activity. Methods: Overall, 61 SLE patients and 60 healthy subjects were enrolled in this cross-sectional study. The Systemic Lupus Erythematosus Disease Activity Index (SLEDAI) score assessed disease activity. Senescence surface markers of CD4 and CD8 T lymphocytes were measured by flow cytometry (CD4/CD8 ratio, CD28 ${ }^{\text {null }}$, CD57, CD45 isoforms [CD45RA and CD45RO], and KLRG1). Enzyme-linked immunosorbent assay (ELISA) was used to measure the serum cytokines (IFNy and IL-2) and cytomegalovirus (CMV) serology. Complement and anti-dsDNA levels were also evaluated as the comparator for predicting active disease in SLE. Logistic regression models were used to identify the independent predictive factors for active SLE status. Performance of the senescence markers in predicting active disease in SLE was analyzed by receiver operating characteristic (ROC) curve as the area under curve (AUC).

Results: SLE patients with active disease had significantly higher CD8 ${ }^{+}$

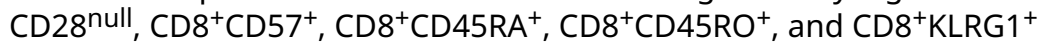
percentages with lower CD4/CD8 ratio than healthy subjects and SLE

\section{Open Peer Review}

\begin{tabular}{cccc} 
Approval Status & \multicolumn{1}{c}{ ? } & \\
& 1 & 2 & 3 \\
\hline version 1 & & $\times$ & $?$ \\
07 Mar 2022 & view & view & view
\end{tabular}

1. Tak Mao Chan (ID), The University of Hong Kong, Hong Kong, China

2. Giuseppe A. Ramirez (iD), Universita Vita

Salute San Raffaele, Milan, Italy

Istituto di Ricovero e Cura a Carattere

Scientifico San Raffaele, Milan, Italy

3. Marija Jelusic (iD), University of Zagreb,

Zagreb, Croatia

Mario Sestan, University of Zagreb, Zagreb, Croatia

Any reports and responses or comments on the article can be found at the end of the article. 
patients with inactive disease. The highest AUC and sensitivity were seen in $C D 8^{+} C D 28$ null (AUC 0.801 [0.662-0.940], sensitivity 91.9\%, cut off $>6.85 \%$ ) with comparable results to serum complement and antidsDNA in predicting active disease. Multivariate analysis showed that $\mathrm{CD} 4 / \mathrm{CD} 8$ ratio, $\mathrm{CD} 8^{+} \mathrm{CD} 28^{\text {null }}$, and $\mathrm{C3}$ had significantly increased $\mathrm{OR}$ for active SLE. Combination models of CD4/CD8 ratio, $C D 8^{+} C D 28$ null, and $C 3$ yielded the best results for predicting the active SLE (AUC 0.923 [0.848-0.997], sensitivity $81.2 \%$, specificity $84.0 \%$, LR+ 5.08 and LR- 0.22).

Conclusions: Our findings demonstrated that combining immunosenescence markers, including CD4/CD8 ratio and CD8+CD28null with C3 levels could increase the odds of predicting active disease in SLE.

\section{Keywords}

immunosenescence, systemic lupus erythematosus, disease activity, senescence markers

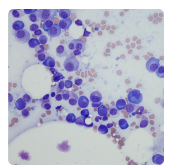

This article is included in the Cell \& Molecular

Biology gateway.

Corresponding author: Mirza Zaka Pratama (mirzazaka.pratama@gmail.com)

Author roles: Handono K: Conceptualization, Formal Analysis, Funding Acquisition, Project Administration, Resources, Supervision, Validation, Writing - Original Draft Preparation, Writing - Review \& Editing; Pratama MZ: Conceptualization, Data Curation, Formal Analysis, Investigation, Methodology, Project Administration, Software, Validation, Visualization, Writing - Original Draft Preparation, Writing - Review \& Editing; Partan RU: Conceptualization, Funding Acquisition, Writing - Original Draft Preparation, Writing - Review \& Editing; Susianti H: Conceptualization, Investigation, Methodology, Writing - Original Draft Preparation, Writing - Review \& Editing; Firdaningrum NE: Data Curation, Formal Analysis, Investigation, Visualization, Writing - Original Draft Preparation, Writing - Review \& Editing; Famuji SRR: Data Curation, Formal Analysis, Investigation, Writing - Original Draft Preparation, Writing - Review \& Editing; Fachry AWR: Data Curation, Formal Analysis, Investigation, Visualization, Writing - Original Draft Preparation, Writing - Review \& Editing; Sumarta NH: Data Curation, Formal Analysis, Visualization, Writing - Original Draft Preparation, Writing - Review \& Editing; Kalim H: Conceptualization, Formal Analysis, Investigation, Methodology, Project Administration, Supervision, Validation, Writing Original Draft Preparation, Writing - Review \& Editing

Competing interests: No competing interests were disclosed.

Grant information: This study was supported by the Indonesian Ministry of Research and Technology in the World Class Research scheme (grant number: 108/E4.1/AK.04.PT/2021).

The funders had no role in study design, data collection and analysis, decision to publish, or preparation of the manuscript.

Copyright: @ 2022 Handono $\mathrm{K}$ et al. This is an open access article distributed under the terms of the Creative Commons Attribution License, which permits unrestricted use, distribution, and reproduction in any medium, provided the original work is properly cited.

How to cite this article: Handono K, Pratama MZ, Partan RU et al. Performance of the T cell senescence markers in predicting the active disease of systemic lupus erythematosus [version 1; peer review: 1 approved, 1 approved with reservations, 1 not approved] F1000Research 2022, 11:285 https://doi.org/10.12688/f1000research.109365.1

First published: 07 Mar 2022, 11:285 https://doi.org/10.12688/f1000research.109365.1 


\section{Introduction}

Systemic lupus erythematosus (SLE) is a chronic autoimmune disease with unclear mechanisms that primarily affect women of children-bearing age. Although the pathogenesis of SLE is not well understood, several predisposing factors are involved in the development of aberrant immune response in SLE, including genetic predisposition, gender, and the environment. ${ }^{1}$ Both innate and adaptive immune systems are involved in the pathogenesis of SLE, which leads to the dysregulation of pro-inflammatory cytokines, autoantibody deposition, oxidative stress, and organs damage. ${ }^{2}$ Recent studies discovered that several autoimmune diseases possess some immune system abnormalities that resemble the typical characteristics of immune dysfunction described in the elderly, called immunosenescence. ${ }^{3,4}$ A previous systematic review demonstrates that the shortened telomere length occurs in SLE in relatively young patients. ${ }^{5}$ Chronic autoantigen stimulation, oxidative stress, or increasing pro-inflammatory cytokines contribute to the replicative stress that accelerates immunosenescence in several autoimmune diseases, including SLE. ${ }^{6,7}$ These findings indicate that patients with autoimmune diseases may have an accelerated immunosenescence, despite being young.

Aging in the immune system is characterized by several $\mathrm{T}$ cell phenotypes and functions changes. Upon repeated activation, T cells progressively downregulate CD28 expression leading to the accumulation of CD28 ${ }^{\text {null }} \mathrm{T}^{\text {cells. }}{ }^{8}$ Moreover, the senescent $\mathrm{T}$ cells also express some additional markers such as killer cell lectin-like receptor subfamily $\mathrm{G}$ (KLRG-1) and CD57. ${ }^{9}$ CD45 isoforms (CD45RA or CD45RO) are also aging features in the immune system. ${ }^{10}$ Terminally differentiated $\mathrm{T}$ cells have been described to re-express the CD45RA, while CD45RO can be found abundantly on $\mathrm{T}$ cell central memory and effector memory that increases during aging. ${ }^{11,12}$ Several cytokines also can be applied as descent markers of immunosenescence. Terminally differentiated $\mathrm{T}$ cells are capable of producing high levels of interferon $\gamma($ IFN $\gamma) .{ }^{13}$ On the other hand, the level of interleukin 2 (IL-2) is progressively declined in elderly people. ${ }^{14}$ Chronic infection, such as CMV, has also been associated with immunosenescence in several populations. A systematic review showed that CMV seemed to enhance immunosenescence by inducing highly differentiated effector memory and T cell effector memory re-expressing CD45RA (TEMRA) cells in CD4 and CD8 pools. ${ }^{15}$

The association between the senescence markers and disease activity in SLE has been described previously but still not given any convincing results yet. Earlier studies indicate that an increasing number of T cell senescence CD4+CD28null correlates with SLICC/ACR damage index in SLE patients. ${ }^{16}$ Research by Ugarte-Gil et al. found that CD4 ${ }^{+} \mathrm{CD} 28^{\text {null }}$ $\mathrm{T}$ cells predict the occurrence of new lung damage in SLE. ${ }^{17}$ Alteration of effector memory T cells $\left(\mathrm{CD} 45 \mathrm{RO}^{+} \mathrm{T}\right.$ cells) was also associated with tissue injury in lupus nephritis. ${ }^{18}$ Terminally differentiated effector memory $\mathrm{T}$ cells $\left(\mathrm{CCR}^{-} \mathrm{CD} 45 \mathrm{RA}^{+}\right)$expand in SLE patients with higher disease activity. In addition, SLE patients with higher Systemic Lupus Erythematosus Disease Activity Index (SLEDAI) scores also had a higher percentage of circulating CD4 ${ }^{+} \mathrm{T}$ cells with CD28 ${ }^{\text {null }}$ phenotype. ${ }^{19}$ Although these senescence markers can be used as potential targets to predict the SLE disease activity, not all senescence markers have been described in SLE patients. Based on these findings, inspecting several senescence markers instead of only one marker at the same time also may increase the probability of predicting SLE disease activity.

The study aimed to identify which senescence markers could be associated with the SLE disease activity. Once the senescence markers were recognized, we would produce a model that showed the best performance to predict the active disease in SLE. We analyzed several senescence markers on both $\mathrm{CD} 4^{+}$and $\mathrm{CD} 8^{+} \mathrm{T}$ cells compartments, including the senescence surface markers, such as CD28, CD57, KLRG1, and CD45 isoforms (RA/RO); cytokines that associated with aging (IFN $\gamma$ and IL-2); and IgG anti-CMV antibody. We also compared the performance of these senescence markers with complements and anti-dsDNA as the conventional biomarkers to predict the active disease in SLE.

\section{Methods}

Study population

This research was a cross-sectional study held from January to November 2021. According to the design of this study, the sample size calculation was done according to the formula for cross-sectional study with quantitative variable with the following equation, sample size $=\left(\mathrm{Z}_{1-\alpha / 2}\right)^{2}(\mathrm{SD})^{2} /(\mathrm{d})^{2.20} \mathrm{Z}_{1-\alpha / 2}$ value was the standardized value for the confidence interval (CI). Because this study used $95 \%$ CI, the Z-score value was 1.96 . The value of standard deviation (SD) and $\mathrm{d}$ score (margin of error) was obtained and calculated from our previous study that mentioned the SD of CD28 $8^{\text {null }} \mathrm{T}$ cells that was 13 and the calculation of d score was 5.4 [Kalim, et al., 2019]. Thus, the minimal sample size of this study was 21 subjects.

In order to minimize the selection bias, the study participants were recruited by simple random sampling. In the end, we recruited 61 female SLE patients referred to the Rheumatology Clinic, Department of Internal Medicine, Saiful Anwar General Hospital, Malang, Indonesia. Patients were approached to take part in this study by several methods, including letter, phone, or direct oral approach in the clinics. Patients who agreed to participate in the study signed the written 
informed consent. All patients aged 18 to 45 years met the 2019 EULAR/ACR criteria for SLE. ${ }^{21}$ The exclusion criteria for the subjects were SLE patients who were pregnant, had an active infection, or had a history of cancer.

All subjects were collected for the demographic data, clinical manifestations, laboratory tests, and past medical history by the rheumatologist as the routine procedures in the clinics. To minimize the information bias, patients were assessed by at least two rheumatologists in the clinic. Patients received standard treatment protocols according to the disease severity. As the comparator, 60 healthy individuals were recruited with matched age, sex, and demographic data that were approached by letters or phone. All healthy subjects were stated as "healthy" by at least two doctors, to minimize the bias, from the General Checkup Clinics of Saiful Anwar General Hospital, Malang, Indonesia after underwent clinical and laboratory examinations as a special appointment for this study and did not have any medical problems by history taking.

\section{Ethical considerations}

Subjects signed an informed consent form before undergoing the study, and Saiful Anwar General Hospital Ethical Committee approved all protocols (Ethical Number 400/085/K.3/302/2020 issued on $23^{\text {rd }}$ March 2020).

\section{Assessment of SLE disease activity}

SLE disease activity was assessed using the Systemic Lupus Erythematosus Disease Activity Index (SLEDAI)-2K score. $^{22}$ The rheumatologist evaluated the SLEDAI score in the Rheumatology Clinics on each visit. The clinically active disease was defined if the SLEDAI score was $>4$. In contrast, the clinically inactive disease or lupus low disease activity (LLDAS) was characterized if the SLEDAI score was $\leq 4$ with no activity in major organ systems (renal, central nervous system (CNS), cardiopulmonary, vasculitis, fever) and no hemolytic anemia or gastrointestinal activity. ${ }^{23}$ The sera of SLE patients were collected during visits and used to measure the C3, C4, and anti-dsDNA examinations. All the laboratory examinations were done in the Central Laboratory Saiful Anwar General Hospital, Malang, Indonesia.

\section{Serum cytokines examinations using enzyme-linked immunosorbent assay (ELISA)}

Several cytokines were measured from the sera of SLE patients and healthy subjects, including IFN $\gamma$ and IL-2. The sera's cytokine levels were measured using the ELISA kits from Biolegend (LEGEND MAX ${ }^{\mathrm{TM}}$ human IFN $\gamma$ ELISA kit [Biolegend, Singapore, cat number 430107] and LEGEND MAX ${ }^{\mathrm{TM}}$ human IL-2 ELISA kit [Biolegend, Singapore, cat number 430107]). Serum IgG CMV levels from both subjects were also measured using a human anti-CMV IgG ELISA kit (Abcam, Singapore, cat number ab108724) to examine the role of CMV infection in the development of immunosenescence in SLE patients. All the procedures were done according to the manufacturer's protocols. In brief, this assay employed the quantitative sandwich enzyme immunoassay technique. A polyclonal antibody specific for IFN $\gamma$, IL-2, or CMV antigens has been precoated onto a microplate. Standards and samples are pipetted into the wells and the measured antigens are bound by the immobilized antibody. After washing away any unbound substances, an enzyme-linked polyclonal antibody is added to the wells. Following a wash to remove any unbound antibody-enzyme reagent, a substrate solution is added to the wells and color develops in proportion to the amount of antigen-antibody bound in the initial step. The color development is stopped and the intensity of the color is measured by the microplate reader (Stat Fax 303 Plus microplate reader). The results of IFN $\gamma$ and IL-2 were measured in $\mathrm{pg} / \mathrm{ml}$ while IgG anti-CMV was in IU/ml.

\section{Measurement of T cells senescence markers using flowcytometry}

Several surface markers associated with the aging of $\mathrm{T}$ lymphocytes were measured from the peripheral blood mononuclear cells (PBMC) of SLE patients and healthy subjects. All subjects had 10-15 cc of vein blood taken, then PBMC were isolated from peripheral blood using Lymphoprep (Stemcell Technology, cat number NC0423266) by centrifugation (Hettich model EBA 200) (1600 g for 30 minutes). The formed PBMC layer was taken slowly and rewashed with ten cc phosphate buffer saline (PBS). The supernatant was discarded and centrifuged (Hettich model EBA 200) at room temperature (1200 $\mathrm{g}$ for 30 minutes).

The PBMC was stained with the following antibodies: APC/Cy7.7 anti-human CD3, FITC anti-human CD4, PerCP antihuman CD8, PE anti-humanCD28, PE anti-human CD57, PE anti-human CD45RA, PE anti-human CD45RO, and Alexa Fluor 488 anti-Human KLRG1. All kits were purchased from Biolegend, and the procedures were done as the manufacturer protocols. $\mathrm{T}$ cells $\left(\mathrm{CD}^{+}\right.$cells) senescence markers which measured were as follows: $\mathrm{CD} 4 / \mathrm{CD} 8$ ratio, $\mathrm{CD} 4^{+} \mathrm{CD} 28^{\text {null }}, \mathrm{CD} 8^{+} \mathrm{CD} 28^{\text {null }}, \mathrm{CD} 4^{+} \mathrm{CD} 57^{+}, \mathrm{CD} 8^{+} \mathrm{CD} 57^{+}, \mathrm{CD} 4^{+} \mathrm{CD} 45 \mathrm{RA}^{+}, \mathrm{CD} 8^{+} \mathrm{CD} 45 \mathrm{RA}^{+}, \mathrm{CD}^{+} \mathrm{CD} 45 \mathrm{RO}^{+}$, $\mathrm{CD}^{+} \mathrm{CD} 45 \mathrm{RO}^{+}, \mathrm{CD}^{+} \mathrm{KLRG}^{+}$, and $\mathrm{CD} 8^{+} \mathrm{KLRG1}^{+}$. The percentages of the cells were acquired with flow cytometry (BD FACScalibur) and analyzed with BD Cell Quest Pro software version 6.0 for Mac. Measurements were made in 10.000 cells, and the results were obtained in the form of percentages $(\%)$ of cells.

Statistical analysis

Statistical analysis was performed using SPSS (IBM SPSS Statistics, RRID:SCR_019096) for Windows version 25.0. Mean \pm standard deviation (SD) was used to describe normally distributed data, the median and interquartile range for 
skewed data, and frequencies of categorical data used the percentages. The Mann-Whitney test compared healthy subjects with SLE patients and active with inactive patients if the data distribution was not normal. Instead, an unpaired t-test was used if the data distribution was normal. Chi-square or Fisher exact test analysis was used to compare two categorical data. Receiver operating characteristics (ROC) curves discriminated active from inactive SLE for each marker. The performance of the senescence markers in predicting the active disease in SLE was shown as the area under curve (AUC). AUC value below 0.5 indicated an inferior model, AUC value more than 0.5 mean that the model is no better at predicting an outcome than random chance, AUC value over 0.7 indicated a good model, values over 0.8 indicated a robust model and a value of 1 means that the model perfectly predicts the outcomes. The optimal cut-off value with the sensitivity, specificity, and likelihood ratio (LR) was also calculated. Logistic regression models were used to identify the independent predictive factors for the active SLE status. The results were considered statistically significant if the p-value was $<0.05$.

\section{Results}

Characteristics of the study population

A total of 61 patients and 60 healthy subjects were included in the analysis of this study. ${ }^{41}$ Study clinicians assessed 128 patients and 83 healthy subjects for eligibility (Figure 1). Healthy subjects were matched for age, race, and sex. Of these, 47 SLE patients (36.7\%) and 14 healthy participants (16.8\%) did not fulfil the inclusion criteria, 11 patients (8.6\%) and four healthy subjects (4.8\%) declined to participate. Amongst the enrolled patients and healthy subjects, nine SLE patients $(7.0 \%)$ and five healthy participants $(6.0 \%)$ were excluded from the analysis because their records or examination results did not complete and insufficient for being analyzed.

According to Table 1, all healthy subjects and SLE patients were women of child-bearing ages, and there was no statistical difference of age between these two groups $(\mathrm{p}=0.108)$. SLE patients were categorized into active and inactive SLE based on the SLEDAI-2K score. Among 61 subjects with SLE, 18 patients (29.5\%) were inactive, and 43 patients $(70.5 \%)$ were active. The median duration of the disease from inactive and active SLE patients was not statistically different (48.0 vs. 44.0 months, respectively, $\mathrm{p}=0.384$ ). Age of onset from the first time diagnosed as SLE was also not statistically different between these two groups $(24.9 \pm 6.1$ vs. $23.2 \pm 5.6$, for inactive and active SLE, respectively, $\mathrm{p}=0.282)$. The mean SLEDAI score from inactive SLE was $1.2 \pm 1.0$, while active SLE was $11.3 \pm 8.1(\mathrm{p}=0.000)$. The significant differences in clinical manifestations between inactive and active SLE were renal involvement, serositis, and vasculitis. In total, 20 patients from the active groups showed symptoms of lupus nephritis $(\mathrm{p}=0.001)$, while ten patients from active SLE groups had symptoms of vasculitis and serositis $(p=0.039)$. All patients from inactive and active SLE groups received standard treatment based on their disease activity. There were no significant differences in the treatment distribution from both groups (Table 1).

\section{Comparison of senescence markers between healthy subjects and SLE patients}

Before determining the possible senescence markers that could predict the disease activity in SLE, we analyzed the comparison between these markers between healthy subjects and SLE patients to find which senescence markers significantly changed in SLE populations. According to Table 2, we demonstrated that SLE patients had a significantly lower CD4/CD8 ratio compared to healthy subjects $(0.6 \pm 0.2$ vs. $1.5 \pm 0.7, p<0.001)$. Among all senescence markers measured in the CD4 T cell population, CD28 ${ }^{\text {null }}$, CD45RO, and KLRG1 were significantly higher in SLE patients than healthy subjects ( $\mathrm{p}<0.001$ for all markers). On the other hand, all senescence markers from the CD8 T cell population,
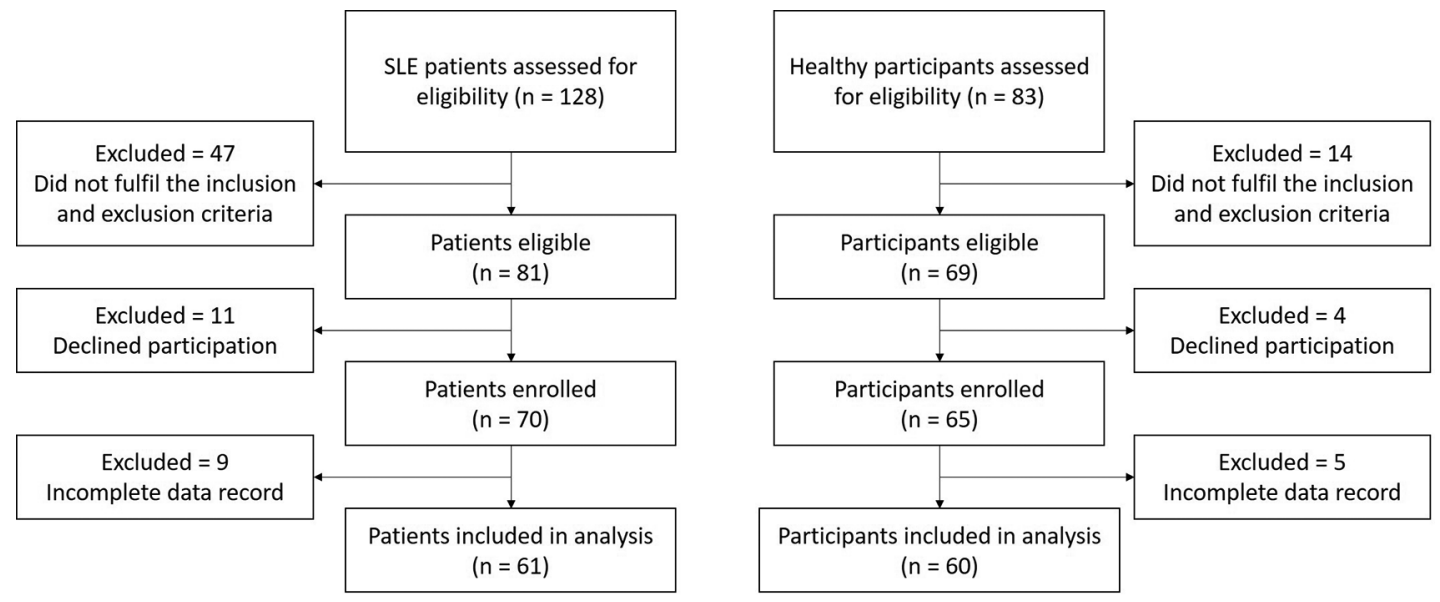

Figure 1. Flowchart of the participants. SLE = systemic lupus erythematosus. 
Table 1. Characteristics of subjects.

\begin{tabular}{|c|c|c|c|c|}
\hline Parameter & $\begin{array}{l}\text { Healthy subjects } \\
(n=60)\end{array}$ & $\begin{array}{l}\text { Inactive SLE } \\
(n=18)\end{array}$ & $\begin{array}{l}\text { Active SLE } \\
(n=43)\end{array}$ & $\mathbf{p}$ \\
\hline Age (year) & $28.3 \pm 3.4$ & $30.2 \pm 7.2$ & $27.0 \pm 5.7$ & 0.108 \\
\hline Disease duration (months) & - & $48.0(19.2-102.0)$ & $44.0(24.0-69.0)$ & 0.384 \\
\hline Age of onset (year) & - & $24.9 \pm 6.1$ & $23.2 \pm 5.6$ & 0.282 \\
\hline SLEDAI score & - & $1.2 \pm 1.0$ & $11.3 \pm 8.1$ & $<0.001$ \\
\hline \multicolumn{5}{|l|}{ Clinical manifestations, n (\%) } \\
\hline - Neuropsychiatric & - & $0(0)$ & $6(9.8)$ & 0.124 \\
\hline - Nephritis & - & $0(0)$ & $20(32.7)$ & 0.001 \\
\hline - Vasculitis & - & $0(0)$ & $10(16.3)$ & 0.039 \\
\hline - Arthritis & - & $2(3.2)$ & $16(26.2)$ & 0.082 \\
\hline - Myositis & - & $0(0)$ & $1(1.6)$ & 0.091 \\
\hline - Serositis & - & $0(0.0)$ & $10(16.3)$ & 0.039 \\
\hline - Fever & - & $0(0)$ & $2(3.2)$ & 0.391 \\
\hline - Thrombocytopenia & - & $0(0)$ & $2(3.2)$ & 0.391 \\
\hline - Leukopenia & - & $4(6.6)$ & $11(18.0)$ & 0.965 \\
\hline - Mucocutaneous & - & $6(9.8)$ & $22(36.1)$ & 0.432 \\
\hline - Fatigue & - & $4(6.6)$ & $20(32.7)$ & 0.334 \\
\hline \multicolumn{5}{|l|}{ Medications, n (\%) } \\
\hline - Steroids & - & $14(22.9)$ & $42(68.8)$ & 0.094 \\
\hline - Hydroxychloroquine & - & $10(16.4)$ & $36(59.0)$ & 0.638 \\
\hline - Azathioprine & - & $4(6.5)$ & $18(29.5)$ & 0.387 \\
\hline - Cyclophosphamide & - & $1(1.6)$ & $3(4.9)$ & 0.895 \\
\hline - Mycophenolate mofetil & - & $1(1.6)$ & $8(13.1)$ & 0.225 \\
\hline
\end{tabular}

Legend: SLE: systemic lupus erythematosus; SLEDAI: SLE disease activity index.

Table 2. Comparison of the senescence markers between healthy individuals and patients with SLE.

\begin{tabular}{|c|c|c|c|}
\hline Variables & $\begin{array}{l}\text { Healthy individuals } \\
(n=60)\end{array}$ & $\begin{array}{l}\text { SLE patients } \\
(n=61)\end{array}$ & $p$ \\
\hline CD4/CD8 ratio & $1.5 \pm 0.7$ & $0.6 \pm 0.2$ & $<0.001$ \\
\hline CD4 $4^{+}$CD28 ${ }^{\text {null }}(\%)$ & $1.5 \pm 0.2$ & $3.1 \pm 2.0$ & $<0.001$ \\
\hline $\mathrm{CD} 8^{+} \mathrm{CD} 28^{\text {null }}(\%)$ & $7.5 \pm 4.7$ & $13.8 \pm 7.8$ & $<0.001$ \\
\hline $\mathrm{CD}^{+} \mathrm{CD}^{\circ} 7^{+}(\%)$ & $1.2 \pm 0.9$ & $1.6 \pm 1.6$ & 0.129 \\
\hline $\mathrm{CD}^{+} \mathrm{CD}^{\circ} 7^{+}(\%)$ & $2.3 \pm 2.0$ & $10.2 \pm 6.0$ & $<0.001$ \\
\hline $\mathrm{CD}^{+} \mathrm{CD}^{2} 5 \mathrm{RA}^{+}(\%)$ & $11.6 \pm 6.4$ & $12.1 \pm 8.5$ & 0.695 \\
\hline $\mathrm{CD}^{+} \mathrm{CD}^{2} 5 \mathrm{RA}^{+}(\%)$ & $9.7 \pm 5.3$ & $23.3 \pm 8.9$ & $<0.001$ \\
\hline $\mathrm{CD}^{+} \mathrm{CD}^{2} 5 \mathrm{RO}^{+}(\%)$ & $2.6 \pm 1.4$ & $14.3 \pm 6.1$ & $<0.001$ \\
\hline $\mathrm{CD}^{+} \mathrm{CD}^{4} 5 \mathrm{RO}^{+}(\%)$ & $2.2 \pm 1.7$ & $9.3 \pm 7.2$ & $<0.001$ \\
\hline $\mathrm{CD}^{+}{ }^{+} \mathrm{KLRG}^{+}{ }^{+}(\%)$ & $0.1 \pm 0.1$ & $3.7 \pm 3.5$ & $<0.001$ \\
\hline $\mathrm{CD}^{+}{ }^{\mathrm{KLRG}} 1^{+}(\%)$ & $0.3 \pm 0.1$ & $12.5 \pm 7.2$ & $<0.001$ \\
\hline IFN $\gamma(p g / m l)$ & $7.1 \pm 2.8$ & $221.7 \pm 137.5$ & $<0.001$ \\
\hline IL2 (pg/ml) & $228.3 \pm 132.5$ & $13.9 \pm 7.5$ & $<0.001$ \\
\hline IgG CMV (U/ml) & $1.6 \pm 0.8$ & $1.8 \pm 0.8$ & 0.512 \\
\hline
\end{tabular}

Legend: SLE: systemic lupus erythematosus; IFN $\gamma$ : interferon $\gamma$; IL2: interleukin-2; IgG CMV: immunoglobulin G cytomegalovirus. 
including CD28 ${ }^{\text {null }}$, CD57, CD45RA, CD45RO, and KLRG1, were significantly higher in SLE patients ( $p<0.001$ for all markers). Examination of the cytokines level revealed that serum IFN $\gamma$ level was markedly higher in SLE patients $(221.7 \pm 137.5 \mathrm{pg} / \mathrm{ml}$ vs. $7.1 \pm 2.8 \mathrm{pg} / \mathrm{ml}, \mathrm{p}<0.001)$. In contrast, a significantly lower IL-2 level was demonstrated in SLE patients compared to healthy subjects $(13.9 \pm 7.5 \mathrm{pg} / \mathrm{ml}$ vs. $228.3 \pm 132.5 \mathrm{pg} / \mathrm{ml}, \mathrm{p}<0.001)$. We did not find significant differences in IgG CMV levels between SLE patients and healthy subjects $(p=0.512)$. According to Table 2 , markers that did not statistically differ between the healthy subjects and SLE patients were excluded for the subsequent analysis.

\section{Comparison of the senescence markers according to the SLE disease activity}

In the next analysis, we compared the senescence markers between active and inactive SLE patients according to the SLEDAI-2K score (Table 3). Our findings showed that among CD4 T cell senescence markers, none of them was statistically different between active and inactive SLE patients. In contrast, all of senescence markers from CD8 T cell populations were significantly higher in active patients compared to inactive patients with SLE, including CD28 ${ }^{\text {null }}$ $(16.1 \pm 7.4 \%$ vs. $8.4 \pm 5.9 \%, p=0.001)$, CD57 (11.9 $\pm 5.8 \%$ vs. $6.3 \pm 4.6 \%, p=0.001)$, CD $45 \mathrm{RA}(25.0 \pm 9.5 \%$ vs. $19.6 \pm 6.6 \%, \mathrm{p}=0.043), \mathrm{CD} 45 \mathrm{RO}(11.1 \pm 7.7 \%$ vs. $6.4 \pm 4.6 \%, \mathrm{p}=0.024)$, and KLRG1 $(14.6 \pm 7.1 \%$ vs. $7.6 \pm 4.7$, $\mathrm{p}<0.001)$. Markedly lower of CD4/CD8 ratio was found in active SLE patients compared to the inactive patients $(0.6 \pm 0.2$ vs. $0.7 \pm 0.2, p=0.026)$. Significantly higher IFN $\gamma$ levels were demonstrated in SLE patients with active disease activity $(241.3 \pm 153.4 \mathrm{pg} / \mathrm{ml}$ vs. $171.1 \pm 62.8 \mathrm{pg} / \mathrm{ml}, \mathrm{p}=0.043)$.

We also analyzed the anti-dsDNA, C3, and C4 serum levels as control markers, because those markers had been established as standard markers to monitor the disease activity in SLE. The anti-dsDNA level was statistically higher in SLE patients with active disease $(138.9 \pm 88.4 \mathrm{IU} / \mathrm{ml}$ vs. $76.5 \pm 72.4 \mathrm{IU} / \mathrm{ml}, \mathrm{p}=0.043)$. On the other hand, C3 and C4 levels were statistically lower in active SLE patients than patients with inactive disease activity $(\mathrm{p}=0.015$ and $\mathrm{p}=0.004$, respectively). All markers that did not statistically differ from the inactive SLE patients were excluded for the subsequent analysis.

Performance of the senescence markers in predicting the active disease in SLE

The ROC curve analysis showing the AUC for each marker in predicting the SLE active disease is presented in Table 4. $\mathrm{C} 3$, as the control marker, had the highest AUC value compared to other markers (AUC 0.844). As for the senescence marker, $\mathrm{CD} 8^{+} \mathrm{CD} 28^{\text {null }}$ had the highest AUC compared to other senescence markers (AUC 0.801). The optimal cut-off value with the sensitivity, specificity, and LR is shown in Table $4 . \mathrm{CD} 8^{+} \mathrm{CD} 28^{\text {null }}$ had the highest sensitivity $(91.9 \%)$ compared to other markers with the lowest negative likelihood ratio $(\mathrm{LR}-=0.13)$ in the cut-off of $>6.85 \%$. The highest specificity was possessed by $\mathrm{C} 3(75 \%)$ in the cut-off $<0.6 \mathrm{~g} / \mathrm{l}$ with the highest positive likelihood ratio (LR+) of 3.09. The senescence markers from the CD8 T cell population, including CD28null, CD57, CD45RA, CD45RO, and KLRG1, had higher sensitivity than anti-dsDNA, C3, or C4.

Table 3. Comparison of senescence markers between inactive and active disease among patients with SLE.

\begin{tabular}{|c|c|c|c|}
\hline Variables & $\begin{array}{l}\text { Inactive } \\
(n=18)\end{array}$ & $\begin{array}{l}\text { Active } \\
(n=43)\end{array}$ & $\mathbf{p}$ \\
\hline CD4/CD8 ratio & $0.7 \pm 0.2$ & $0.6 \pm 0.2$ & 0.026 \\
\hline $\mathrm{CD} 4^{+} \mathrm{CD} 28^{\text {null }}(\%)$ & $1.4 \pm 1.4$ & $3.6 \pm 2.3$ & 0.301 \\
\hline CD8 ${ }^{+} C D 28^{\text {null }}(\%)$ & $8.4 \pm 5.9$ & $16.1 \pm 7.4$ & 0.001 \\
\hline $\mathrm{CD}^{+} \mathrm{CD}^{2} 7^{+}(\%)$ & $6.3 \pm 4.6$ & $11.9 \pm 5.8$ & 0.001 \\
\hline $\mathrm{CD}^{+} \mathrm{CD}^{2} 5 \mathrm{RA}^{+}(\%)$ & $19.6 \pm 6.6$ & $25.0 \pm 9.5$ & 0.043 \\
\hline $\mathrm{CD}^{+} \mathrm{CD} 45 \mathrm{RO}^{+}(\%)$ & $12.3 \pm 6.1$ & $15.2 \pm 5.9$ & 0.117 \\
\hline $\mathrm{CD}^{+} \mathrm{CD}^{2} 5 \mathrm{RO}^{+}(\%)$ & $6.4 \pm 4.6$ & $11.1 \pm 7.7$ & 0.024 \\
\hline $\mathrm{CD}^{+}{ }^{+} \mathrm{KLRG}^{+}(\%)$ & $3.1 \pm 2.9$ & $4.0 \pm 3.8$ & 0.552 \\
\hline $\mathrm{CD}^{+}{ }^{\mathrm{KLRG}} 1^{+}(\%)$ & $7.6 \pm 4.7$ & $14.6 \pm 7.1$ & $<0.001$ \\
\hline IFN $\gamma(\mathrm{pg} / \mathrm{ml})$ & $171.1 \pm 62.8$ & $241.3 \pm 153.4$ & 0.014 \\
\hline IL2 (pg/ml) & $13.4 \pm 8.8$ & $14.2 \pm 6.9$ & 0.729 \\
\hline anti-dsDNA (IU/ml) & $76.5 \pm 72.4$ & $138.9 \pm 88.4$ & 0.043 \\
\hline C3 (g/l) & $1.1 \pm 1.1$ & $0.4 \pm 0.2$ & 0.015 \\
\hline C4 (g/l) & $0.4 \pm 0.3$ & $0.1 \pm 0.1$ & 0.004 \\
\hline
\end{tabular}

Legend: IFN $\gamma$ : interferon $\gamma$; IL2: interleukin-2; anti-dsDNA: anti-double stranded DNA. 
Table 4. Performance of the markers to predict active disease in patients with SLE.

\begin{tabular}{|c|c|c|c|c|c|c|c|}
\hline Biomarker & AUC & $95 \% \mathrm{CI}$ & Cut off & Sensitivity & Specificity & LR+ & LR- \\
\hline CD4/CD8 ratio & 0.718 & $0.562-0.873$ & $<0.67$ & $71.4 \%$ & $71.4 \%$ & 2.50 & 0.40 \\
\hline $\mathrm{CD} 8^{+} \mathrm{CD} 28^{\text {null }}$ & 0.801 & $0.662-0.940$ & $>6.85 \%$ & $91.9 \%$ & $62.5 \%$ & 2.45 & 0.13 \\
\hline $\mathrm{CD}^{+} \mathrm{CD}^{2} 7^{+}$ & 0.791 & $0.654-0.927$ & $>6.82 \%$ & $86.5 \%$ & $68.8 \%$ & 2.77 & 0.20 \\
\hline $\mathrm{CD}^{+} \mathrm{CD}^{2} 5 \mathrm{RA}^{+}$ & 0.684 & $0.536-0.832$ & $>18.65 \%$ & $80 \%$ & $50 \%$ & 1.60 & 0.40 \\
\hline $\mathrm{CD}^{+} \mathrm{CD}^{-} 4 \mathrm{RO}^{+}$ & 0.701 & $0.548-0.854$ & $>3.97 \%$ & $91.7 \%$ & $44.2 \%$ & 1.64 & 0.19 \\
\hline $\mathrm{CD}^{+}{ }^{+} \mathrm{LRG} 1^{+}$ & 0.783 & $0.660-0.906$ & $>7.15 \%$ & $89.7 \%$ & $52.9 \%$ & 1.90 & 0.19 \\
\hline IFN $\gamma$ & 0.664 & $0.516-0.813$ & $>148.45 \mathrm{pg} / \mathrm{ml}$ & $72.7 \%$ & $58.8 \%$ & 1.76 & 0.46 \\
\hline anti-dsDNA & 0.742 & $0.573-0.912$ & $>100 \mathrm{IU} / \mathrm{ml}$ & $57.6 \%$ & $72.7 \%$ & 2.11 & 0.58 \\
\hline C3 & 0.844 & $0.747-0.942$ & $<0.6 \mathrm{~g} / \mathrm{l}$ & $77.3 \%$ & $75 \%$ & 3.09 & 0.30 \\
\hline $\mathrm{C} 4$ & 0.799 & $0.681-0.918$ & $<0.2 \mathrm{~g} / \mathrm{l}$ & $70.5 \%$ & $76.5 \%$ & 3.00 & 0.39 \\
\hline
\end{tabular}

Legend: AUC: area under curve; CI: confidence interval; LR: likelihood ratio; IFN $\gamma$ : interferon $\gamma$; anti-dsDNA: anti-double stranded DNA.

The logistic regression models for the markers in predicting active disease of SLE

Univariate and multivariate analysis using the logistic regression for the markers to predict the active disease of SLE is presented in Table 5. We used the cut-value from the prior ROC analysis to define the upper and lower value from the markers. The univariate analysis yielded statistically significant OR for active SLE by the following markers: CD4/CD8 ratio, $\mathrm{CD}^{+} \mathrm{CD} 28^{\text {null }}, \mathrm{CD}^{+} \mathrm{CD}^{+} 7^{+}, \mathrm{CD}^{+} \mathrm{CD}^{2} 5 \mathrm{RA}^{+}, \mathrm{CD}^{+} \mathrm{CD} 45 \mathrm{RO}^{+}, \mathrm{CD}^{+} \mathrm{KLRG}^{+}, \mathrm{IFN} \gamma, \mathrm{C} 3$, and $\mathrm{C} 4$. According to the multivariate analysis, CD4/CD8 ratio (OR 9.1 [95\% CI 2.2-37.6], $\mathrm{p}=0.002), \mathrm{CD}^{+} \mathrm{CD} 28^{\text {null }}(\mathrm{OR} 25.5$ [95\% CI $5.1-$ 128.2], $\mathrm{p}<0.001$ ), and C3 (OR 17.9 [95\% CI $2.1-155.2$ ], $\mathrm{p}=0.006)$ had significant association with the active disease of SLE from the participants.

Performance of the combined marker models in predicting the active disease of SLE

According to the multivariate analysis, we demonstrated that $\mathrm{CD} 4 / \mathrm{CD} 8$ ratio, $\mathrm{CD} 8{ }^{+} \mathrm{CD} 28^{\text {null }}$, and $\mathrm{C} 3$ yielded a significant association with active disease of SLE in our subjects. Thus, our subsequent analysis was to observe the performance of the combined model of these markers to predict the active disease of SLE. The ROC curve analysis of the combined marker showing the AUC, sensitivity, specificity, and LR was presented in Table 6. Overall, using the combined marker models had a better AUC value compared to the previous single marker in predicting the active disease of SLE. The combination of T cell senescence markers, CD4/CD8 ratio, and CD8 ${ }^{+} \mathrm{CD} 28^{\text {null }}$ had an AUC value of 0.859 with a sensitivity of $87.5 \%$ and specificity of $64.3 \%$. The best AUC value was demonstrated from the combination model of CD4/CD8 ratio, CD8 ${ }^{+} \mathrm{CD} 28^{\text {null }}$, and C3 (AUC 0.923 ) with sensitivity of $81.2 \%$ and specificity of $84.0 \%$. Our finding also showed that the sensitivity, specificity, and LR+ from the combination model from all three parameters were higher than standard C3, C4, or anti-dsDNA as control markers for disease activity in SLE.

Table 5. Logistic regression analysis for the markers in predicting the active disease in patients with SLE.

\begin{tabular}{|c|c|c|c|c|}
\hline \multirow[t]{2}{*}{ Biomarkers } & \multicolumn{2}{|l|}{ Univariate analysis } & \multicolumn{2}{|c|}{ Multivariate analysis } \\
\hline & OR $(95 \% \mathrm{CI})$ & $\mathbf{p}$ & OR $(95 \% \mathrm{CI})$ & p \\
\hline CD4/CD8 ratio $(<0.67)$ & $7.5(2.0-27.9)$ & 0.001 & $9.1(2.2-37.6)$ & 0.002 \\
\hline $\mathrm{CD}^{+} \mathrm{CD}^{2} 8^{\text {null }}(>6.85 \%)$ & $25.1(5.6-116.6)$ & $<0.001$ & $25.5(5.1-128.2)$ & $<0.001$ \\
\hline $\mathrm{CD}^{+} \mathrm{CD}^{2} 7^{+}(>6.82 \%)$ & $14.3(3.7-55.9)$ & $<0.001$ & $5.2(0.1-201.9)$ & 0.380 \\
\hline $\mathrm{CD}^{+} \mathrm{CD}^{2} 5 \mathrm{RA}^{+}(>18.65 \%)$ & $4.7(1.4-16.4)$ & 0.011 & $0.2(0.1-6.0)$ & 0.322 \\
\hline $\mathrm{CD}^{+} \mathrm{CD}^{+} 5 \mathrm{RO}^{+}(>3.97 \%)$ & $5.5(1.5-20.9)$ & 0.009 & $1.0(0.1-19.2)$ & 0.994 \\
\hline $\mathrm{CD}^{+} \mathrm{KLRG}^{+}(>7.15 \%)$ & $11.3(2.8-45.7)$ & $<0.001$ & $41.5(0.9-201.2)$ & 0.060 \\
\hline IFN $\gamma(>148.45 \mathrm{pg} / \mathrm{ml})$ & $3.4(1.1-10.9)$ & 0.034 & $7.4(0.9-56.6)$ & 0.059 \\
\hline anti-dsDNA (>100 IU/ml) & $3.1(0.9-9.7)$ & 0.053 & $1.8(0.5-6.9)$ & 0.406 \\
\hline C3 $(<0.6 \mathrm{~g} / \mathrm{l})$ & $28.0(3.9-231.3)$ & $<0.001$ & $17.9(2.1-155.2)$ & 0.006 \\
\hline $\mathrm{C} 4(<0.2 \mathrm{~g} / \mathrm{l})$ & $10.0(1.22-83.04)$ & 0.012 & $4.6(0.5-45.2)$ & 0.192 \\
\hline
\end{tabular}

Legend: OR: odd ratio; CI: confidence interval; IFN $\gamma$ : interferon $\gamma$; anti-dsDNA: anti-double stranded DNA. 
Table 6. Performance of the combined models to predict an active disease in patients with SLE.

\begin{tabular}{|c|c|c|c|c|c|c|}
\hline Model & AUC & $95 \% \mathrm{CI}$ & Sensitivity & Specificity & LR+ & LR- \\
\hline $\mathrm{CD} 4: \mathrm{CD} 8$ ratio and $\mathrm{CD} 8^{+} \mathrm{CD} 28^{\text {null }}$ & 0.859 & $0.738-0.979$ & $87.5 \%$ & $64.3 \%$ & 2.45 & 0.19 \\
\hline CD4:CD8 ratio and C3 & 0.893 & $0.807-0.979$ & $93.8 \%$ & $64.3 \%$ & 2.63 & 0.10 \\
\hline $\mathrm{CD} 8^{+} \mathrm{CD} 28^{\text {null }}$ and $\mathrm{C} 3$ & 0.884 & $0.786-0.983$ & $94.1 \%$ & $63.6 \%$ & 2.59 & 0.09 \\
\hline $\mathrm{CD} 4: \mathrm{CD} 8$ ratio, $\mathrm{CD} 8^{+} \mathrm{CD} 28^{\text {null }}$, and $\mathrm{C} 3$ & 0.923 & $0.848-0.997$ & $81.2 \%$ & $84.0 \%$ & 5.08 & 0.22 \\
\hline
\end{tabular}

\section{Discussion}

Immunosenescence is a dynamic alteration of immune systems related to the aging process. ${ }^{24}$ Although immunosenescence has been studied in all immune system cells, CD4 or CD8 T cell senescence is the primary immune aging component associated with several pathologies. ${ }^{25}$ Several markers that are associated with the T cell senescence have already been reported, including the surface markers (CD28 ${ }^{\text {null }}, \mathrm{CD} 57, \mathrm{CD} 45$ isoforms, or KLRG1) and cytokines (IFN $\gamma$ or IL-2) ${ }^{8-15}$ Although several immunosenescence markers have been discovered, not all of these markers are exclusively studied in SLE. Our findings demonstrated significant changes in the T cell senescence markers in the SLE patients compared to healthy individuals of similar age. We showed that all senescence markers from CD8 T cell surface (CD28 ${ }^{\text {null }}, \mathrm{CD} 57, \mathrm{CD} 45$ isoforms, and KLRG1) were significantly higher in the SLE patients; instead, only some surface markers were elevated in the CD4 $\mathrm{T}$ cell populations (CD28 ${ }^{\text {null }}, \mathrm{CD} 45 \mathrm{RO}$, and KLRG1). These findings suggested that CD8 $\mathrm{T}$ cells might be more susceptible to aging compared to the CD4 T cells in SLE.

Some evidence suggested that CD4 and CD8 T cells behave differently in response to aging. A previous study showed that CD4 T cells might be a more stable cell type, with lesser susceptibility to age-dependent phenotypic and functional change. ${ }^{26}$ In contrast, CD8 T cells were intrinsically more susceptible to phenotypic changes related to aging. For instance, the rate of CD28 loss in CD8 T cells was faster than in the CD4 T cells populations. A phenotypic shift of the central memory $\mathrm{T}$ cells was more pronounced in CD8 T cells than CD4 compartments. ${ }^{27}$ In addition, senescent CD8 T cells reduced their apoptosis capability and diminished caspase 3 activity. ${ }^{28}$ This phenomenon would increase CD8 T cells, whereas CD4 T cells were decreasing in aging populations, characterized by the inverse ratio of CD4/CD8 T cells. Consistent with the previous study, ${ }^{29}$ our results also showed an inverse ratio of CD4/CD8 T cells in SLE patients.

The relationship between the disease activity and the aged CD8 T cells in SLE might be because of the ability to secrete the pro-inflammatory cytokines, such as IFN $\gamma$, which could worsen the inflammatory responses. The role of IFN $\gamma$ for disease activity and organ damages in SLE had been reviewed previously. ${ }^{30}$ Our analysis found that IFN $\gamma$ levels were significantly higher in SLE patients with active disease. Similar to our study, memory T cells (central and effector memory) were capable of producing high levels of IFN $\gamma$ instead of other cytokines (TNF $\alpha$, IL-4, or IL-5). ${ }^{13}$ Expanded $\mathrm{CD}^{+} \mathrm{CD} 57$ subpopulation also correlated with the increase of IFN $\gamma$ levels in another study. ${ }^{31}$

Most studies emphasized the importance of chronic viral infection, such as CMV infection, in the progression of immunosenescence during aging. The inflammatory response initiated by CMV can lead to the immune system remodeling contributed to the aging process. ${ }^{32}$ However, we showed that IgG CMV antibodies were similar in both SLE patients and healthy subjects. These results might explain that there was no role of CMV infection in developing immunosenescence in SLE.

Although some senescence markers were significantly higher in active SLE patients, head-to-head comparison between the senescence markers with conventional markers (complement or anti-dsDNA) to predict the disease activity in SLE was never described in the previous study. Our data demonstrated that $\mathrm{CD} 8^{+} \mathrm{CD} 28^{\text {null }}$ showed a higher sensitivity with comparable AUC to predict the active SLE than complement or anti-dsDNA levels. Among the senescence markers analyzed in this study, only CD4/CD8 ratio and $\mathrm{CD} 8^{+} \mathrm{CD} 28^{\text {null }}$ had significantly increased OR from the multivariate analysis. In addition, $\mathrm{C} 3$ levels also had an increased OR significantly from the multivariate analysis. Our study revealed that using a combination of the senescence markers $\left(\mathrm{CD} 4 / \mathrm{CD} 8\right.$ ratio and $\left.\mathrm{CD} 8^{+} \mathrm{CD} 28^{\text {null }}\right)$ with the $\mathrm{C} 3$ levels to predict the active disease in SLE produced the highest result AUC with better sensitivity, specificity, and LR value compared to single-use of the marker.

The CD4/CD8 ratio and $\mathrm{CD} 8^{+} \mathrm{CD} 28^{\text {null }}$ were already described in the previous study as immune risk profile (IRP). IRP consisted of several laboratory markers: a low CD4/CD8 T-cell ratio, an expansion of CD8+CD28- T-cells, and cytomegalovirus (CMV) seropositivity. ${ }^{33}$ In contrast to our present study, we did not find any association between CMV seropositivity with the disease activity in SLE. The presence of IRP characterized by the low CD4/CD8 ratio and 
expansion of $\mathrm{CD}^{+} \mathrm{CD} 28^{\text {null }} \mathrm{T}$ cell in the elderly was associated with poor life expectancy and increased mortality or morbidity. ${ }^{34,35}$ Unlike our study, Ugarte et al. demonstrated that, instead of CD ${ }^{+} \mathrm{CD} 28^{\text {null }} \mathrm{T}$ cells, CD $4{ }^{+} \mathrm{CD} 28^{\text {null }} \mathrm{T}$ cells predicted lung damage in SLE patients with hazard ratio (HR) 1.042. ${ }^{17}$ Another study showed that terminally differentiated CD8 T cells were associated with renal pathology in patients with lupus nephritis. ${ }^{36}$ In addition, Winchester et al. also showed that CD8 CD28 $8^{\text {null }}$ T cells were mainly found on the kidney tissue of lupus nephritis patients, indicating the possible role in promoting tissue injury in lupus nephritis. ${ }^{37}$ Despite that, the role of aged CD8 T cells in non-renal SLE manifestation was never described.

In our understanding, this is the first study that described the role of several immunosenescence markers in predicting the active disease of SLE. We also demonstrated that by combining the senescence and conventional markers could provide a better value in predicting the active disease of SLE. In addition, SLE is a complex autoimmune disease with multiple pathways of pathogenesis. Therefore, by understanding some other mechanisms that led to the disease progressivity in SLE, we hope that this disease can be more preventable and curable in the future. However, there are still limitations in this current study. We still could not explain the possible mechanism on how the T cell senescence might affect the disease severity of SLE. A previous study demonstrated that the senescent T cells might affect the disease activity by secreting the inflammatory cytokines. ${ }^{38}$ However, we did not demonstrate any association of IFN $\gamma$ with the disease activity in this study. IFN $\gamma$ is an abundance cytokine produced by several cells, not only the senescent $\mathrm{T}$ cells. Therefore, it is not clear that the increase of the IFN $\gamma$ in this study was solely caused by the senescent T cells. However, previous studies still showed the role of pathogenic senescent $\mathrm{T}$ cells in promoting inflammation in certain conditions. ${ }^{39,40}$ Thus, we still suspected that there might be other cytokines or molecules associated with the disease progression in SLE because of the $\mathrm{T}$ cell senescence.

In conclusion, all analyses demonstrated that two senescence markers $\left(C D 4 / C D 8\right.$ ratio and $\left.C D 8^{+} \mathrm{CD} 28^{\text {null }}\right)$ predicted the SLE disease activity with good sensitivity and specificity. Combined with the conventional markers of C3 might better predict the active disease of SLE. However, the progressivity of disease activity in SLE is a dynamic process; therefore, a longitudinal study over a long period is still needed to convince the role of immunosenescence in the disease progression of SLE. These findings may help to understand better the immunopathogenesis of SLE, and also, these senescence markers may be potential targets as a diagnostic or prognostic marker or even as a marker to monitor the therapy.

\section{Data availability}

Underlying data

Figshare: Data. https://doi.org/10.6084/m9.figshare.19100306. ${ }^{41}$

Data are available under the terms of the Creative Commons Attribution 4.0 International license (CC-BY 4.0).

\section{Acknowledgments}

The author thanks dr. Bagus Putu Putra Suryana, SpPD-KR, for allowing us to use his patients as subjects in this research. We also thank Mr Wahyudha for helping assist in the flow cytometry analysis at the Biomedical Laboratory, Faculty of Medicine Universitas Brawijaya.

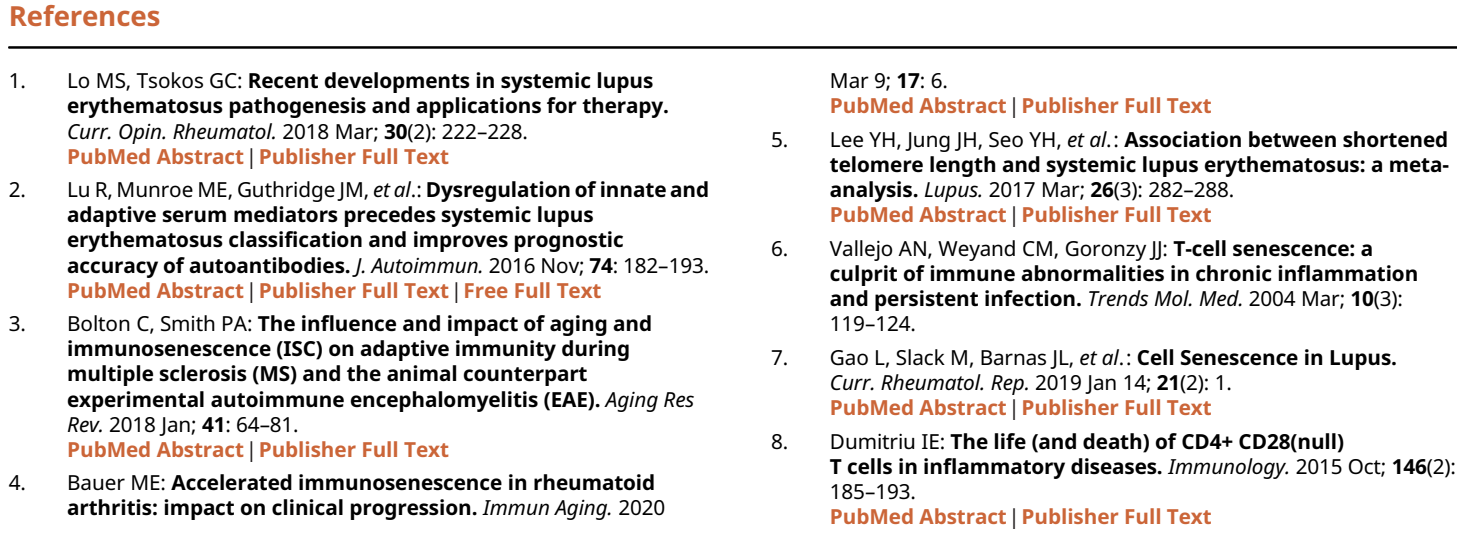

1. Lo MS, Tsokos GC: Recent developments in systemic lupus Mar 9; 17: 6.

4. Bauer ME: Accelerated immunosenescence in rheumatoid arthritis: impact on clinical progression. Immun Aging. 2020

PubMed Abstract | Publisher Full Text

5. Lee $\mathrm{YH}$, Jung JH, Seo YH, et al.: Association between shortened telomere length and systemic lupus erythematosus: a metaanalysis. Lupus. 2017 Mar; 26(3): 282-288.

PubMed Abstract | Publisher Full Text

6. Vallejo AN, Weyand CM, Goronzy JJ: T-cell senescence: a culprit of immune abnormalities in chronic inflammation and persistent infection. Trends Mol. Med. 2004 Mar; 10(3): and persiste

7. Gao L, Slack M, Barnas JL, et al.: Cell Senescence in Lupus. Curr. Rheumatol. Rep. 2019 Jan 14; 21(2): 1. PubMed Abstract | Publisher Full Text

8. Dumitriu IE: The life (and death) of CD4+ CD28(null) T cells in inflammatory diseases. Immunology. 2015 Oct; 146(2): 185-193.

PubMed Abstract | Publisher Full Text 
9. Kared $\mathrm{H}$, Martelli S, Ng TP, et al.: CD57 in human natural killer cells and T-Iymphocytes. Cancer Immunol. Immunother. 2016 Apr; 65(4): 441-452.

Publisher Full Text

10. Rheinländer A, Schraven B, Bommhardt U: CD45 in human physiology and clinical medicine. Immunol. Lett. $2018 \mathrm{Apr}$; 196: 22-32.

Publisher Full Text

11. Henson SM, Riddell NE, Akbar AN: Properties of end-stage human T cells defined by CD45RA re-expression. Curr. Opin. Immunol. 2012 Aug; 24(4): 476-481.

PubMed Abstract | Publisher Full Text

12. Xie $Y$, Luo BW, Yuan XD, et al.: Expression Characteristics of Surface Markers of Memory T cells, CD45RO, CCR7 and CD62L, in Tumor-infiltrating Lymphocytes in Liver Cancer Tissues of Patients with Hepatocellular Carcinomas. J. Clin. Cell Immunol. 2013; 4(181): 2 .

13. Oxenkrug G: Interferon-gamma - Inducible Inflammation: Contribution to Aging and Aging-Associated Psychiatric Disorders. Aging Dis. 2011 Dec; 2(6): 474-486. PubMed Abstract

14. Fulop $\mathrm{T}$, Larbi $\mathrm{A}$, Douziech $\mathrm{N}$, et al.: Cytokine receptor signalling and aging. Mech. Aging Dev. 2006 Jun; 127(6): 526-537. Publisher Full Text

15. Weltevrede M, Eilers R, de Melker HE, et al.: Cytomegalovirus persistence and T-cell immunosenescence in people aged fifty and older: A systematic review. Exp. Gerontol. 2016 May; 77: 87-95. PubMed Abstract | Publisher Full Text

16. Ugarte-Gil MF, Sánchez-Zúñiga C, Gamboa-Cárdenas RV, et al.: Circulating CD4+CD28null and extra-thymic CD4+CD8+ double positive $T$ cells are independently associated with disease damage in systemic lupus erythematosus patients. Lupus. 2016 Mar; 25(3): 233-240.
PubMed Abstract | Publisher Full Text

17. Ugarte-Gil MF, Sánchez-Zúñiga C, Gamboa-Cardenas RV, et al. Peripheral CD4+CD28null T-cells as predictors of damage in systemic lupus erythematosus patients. Clin. Exp. Rheumatol. 2018 Nov-Dec; 36(6): 1008-1013. PubMed Abstract

18. Kosalka J, Jakiela B, Musial J: Changes of memory B- and T-cell subsets in lupus nephritis patients. Folia Histochem. Cytobiol. 2016; 54(1): 32-41.

PubMed Abstract | Publisher Full Text

19. Piantoni S, Regola F, Zanola A, et al.: Effector T-cells are expanded in systemic lupus erythematosus patients with high disease activity and damage indexes. Lupus. 2018 Jan; 27(1): 143-149.

PubMed Abstract | Publisher Full Text

20. Charan J, Biswas T: How to calculate sample size for different study designs in medical research?. Indian J. Psychol. Med. 2013 Apr; 35(2): 121-126.

PubMed Abstract | Publisher Full Text

21. Aringer $M$, Costenbader $K$, Daikh D, et al.: 2019 European League Against Rheumatism/American College of Rheumatology Classification Criteria for Systemic Lupus Erythematosus. Arthritis Rheumatol. 2019 Sep; 71(9): 1400-1412.

PubMed Abstract | Publisher Full Text

22. Gladman DD, Ibañez D, Urowitz MB: Systemic lupus erythematosus disease activity index 2000. J. Rheumatol. 2002 Feb; 29(2): 288-291. PubMed Abstract

23. Franklyn K, Lau CS, Navarra SV, et al.: Definition and initial validation of a Lupus Low Disease Activity State (LLDAS). Ann. Rheum. Dis. 2016 Sep; 75(9): 1615-1621. PubMed Abstract | Publisher Full Text

24. Castelo-Branco C, Soveral I: The immune system and aging: a review. Gynecol. Endocrinol. 2014 Jan; 30(1): 16-22. Publisher Full Text
25. Goronzy JJ, Lee WW, Weyand CM: Aging and T-cell diversity. Exp. Gerontol. 2007 May; 42(5): 400-406. PubMed Abstract | Publisher Full Text Epub 2007 Jan 10.

26. Hu B, Jadhav RR, Gustafson CE, et al.: Distinct Age-Related Epigenetic Signatures in CD4 and CD8 T Cells. Front. Immunol. 2020 Nov 11; 11: 585168.

PubMed Abstract | Publisher Full Text

27. Czesnikiewicz-Guzik M, Lee WW, Cui $D$, et al.: T cell subset-specific susceptibility to aging. Clin. Immunol. 2008 Apr; 127(1): 107-118. PubMed Abstract | Publisher Full Text

28. McComb S, Mulligan R, Sad S: Caspase-3 is transiently activated without cell death during early antigen driven expansion of CD8(+) T cells in vivo. PLoS One. 2010 Dec 22; 5(12): e15328. PubMed Abstract | Publisher Full Text

29. Maeda N, Sekigawa I, Iida N, et al.: Relationship between CD4+/ CD8+ $T$ cell ratio and $T$ cell activation in systemic lupus erythematosus. Scand. J. Rheumatol. 1999; 28(3): 166-170. PubMed Abstract

30. Hayashi T: Therapeutic strategies for SLE involving cytokines: mechanism-oriented therapies especially IFN-gamma targeting gene therapy.J. Biomed. Biotechnol. 2010; 2010: 1-19. Publisher Full Text

31. Bandrés E, Merino J, Vázquez B, et al.: The increase of IFN-gamma production through aging correlates with the expanded CD8 (+high)CD28(-)CD57(+) subpopulation. Clin. Immunol. 2000 Sep; 96(3): 230-235.

PubMed Abstract | Publisher Full Text

32. Pawelec G, Derhovanessian E, Larbi A, et al.: Cytomegalovirus and human immunosenescence. Rev. Med. Virol. 2009 Jan; 19(1): 47-56. Publisher Full Text

33. Ndumbi P, Gilbert L, Tsoukas CM: Comprehensive evaluation of the immune risk phenotype in successfully treated HIV-infected individuals. PLoS One. 2015 Feb 3; 10(2): e0117039. PubMed Abstract | Publisher Full Text

34. Wikby A, Johansson B, Olsson J, et al.: Expansions of peripheral blood CD8 T-lymphocyte subpopulations and an association with cytomegalovirus seropositivity in the elderly: the Swedish NONA immune study. Exp. Gerontol. 2002 Jan-Mar; 37(2-3): 445-453. PubMed Abstract | Publisher Full Text

35. Plonquet A, Bastuji-Garin S, Tahmasebi F, et al.: Immune risk phenotype is associated with nosocomial lung infections in elderly in-patients. Immun. Aging. 2011 Oct 1; 8: 8. PubMed Abstract | Publisher Full Text

36. Żabiń ska M, Krajewska M, Kościelska-Kasprzak K, et al.: CD3(+)CD8 (+)CD28(-) T Lymphocytes in Patients with Lupus Nephritis. J Immunol Res. 2016; 2016: 1-7. Publisher Full Text

37. Winchester $\mathrm{R}$, Wiesendanger $\mathrm{M}$, Zhang $\mathrm{HZ}$, et al.: Immunologic characteristics of intrarenal T cells: trafficking of expanded CD8+ $T$ cell $\beta$-chain clonotypes in progressive lupus nephritis. Arthritis Rheum. 2012 May; 64(5): 1589-1600. PubMed Abstract | Publisher Full Text

38. Kosmaczewska A, Ciszak L, Stosio M, et al.: CD4+CD28null T cells are expanded in moderately active systemic lupus erythematosus and secrete pro-inflammatory interferon gamma, depending on the Disease Activity Index. Lupus. 2020 Jun; 29(7): 705-714. PubMed Abstract | Publisher Full Text

39. Bullenkamp J, Mengoni V, Kaur S, et al.: Interleukin-7 and interleukin-15 drive CD4+CD28null T lymphocyte expansion and function in patients with acute coronary syndrome. Cardiovasc. Res. 2021 Jul 7; 117(8): 1935-1948.

PubMed Abstract | Publisher Full Text

40. Hodge G, Hodge S: Steroid Resistant CD8+CD28null NKT-Like Proinflammatory Cytotoxic Cells in Chronic Obstructive Pulmonary Disease. Front. Immunol. 2016 Dec 19; 7: 617 Publisher Full Text

41. Pratama MZ: Data. figshare. Dataset. 2022. Publisher Full Text 


\section{Open Peer Review}

\section{Current Peer Review Status: $\checkmark \times$ ?}

\section{Version 1}

Reviewer Report 09 March 2023

https://doi.org/10.5256/f1000research.120854.r163469

(C) 2023 Jelusic $\mathbf{M}$ et al. This is an open access peer review report distributed under the terms of the Creative Commons Attribution License, which permits unrestricted use, distribution, and reproduction in any medium, provided the original work is properly cited.

\section{Marija Jelusic \\ School of Medicine, University of Zagreb, Zagreb, Croatia}

\section{Mario Sestan}

School of Medicine, Department of Paediatics, University of Zagreb, Zagreb, Croatia

The manuscript by Handono et al. is a research article aimed to investigate the ability of immunosenescence markers to predict SLE disease activity. It is interesting and clearly written.

A few questions/comments for the authors.

1. In this cohort of patients with SLE, there are exclusively women, which is not unusual since SLE in adulthood affects predominantly women, in contrast to childhood, when the ratio between affected girls and boys is much smaller. Would the results have been different if the authors had included men with SLE in the cohort? Are there gender differences with respect to immunosenescence?

2. It would be interesting to compare senescence markers not only between patients with active and inactive disease, but also between patients with and without kidney disease, then between patients with and without vasculitis, between patients with and without arthritis, etc.

3. Among other things, the authors pointed out that CD8+ cells may be more sensitive to aging than CD4+ cells in SLE. Does this realization have any practical meaning?

4. What is the influence of drugs (immunosuppressants) on immunosenescence? For example, the authors state that 4/18 patients with inactive disease and 18/43 with active disease were treated with azathioprine. It would be interesting to compare whether there are differences in patients who were treated with azathioprine compared to those who were not. It would be interesting to compare the cumulative doses of glucocorticoids with which patients with active and inactive disease were treated, and also try to check whether the dose of glucocorticoids affects immunosenescence? 
5. I draw attention to the fact that CMV serology is not a good indicator of chronic CMV infection, but CMV DNA is (for example, Li H, et al. Exp Gerontol. 2014;54:84-9¹).

\section{References}

1. Li H, Weng P, Najarro K, Xue QL, et al.: Chronic CMV infection in older women: longitudinal comparisons of CMV DNA in peripheral monocytes, anti-CMV IgG titers, serum IL-6 levels, and CMV pp65 (NLV)-specific CD8(+) T-cell frequencies with twelve year follow-up.Exp Gerontol. 2014; 54 : 84-9 PubMed Abstract | Publisher Full Text

Is the work clearly and accurately presented and does it cite the current literature? Yes

Is the study design appropriate and is the work technically sound? Yes

Are sufficient details of methods and analysis provided to allow replication by others? Yes

If applicable, is the statistical analysis and its interpretation appropriate? Partly

Are all the source data underlying the results available to ensure full reproducibility? Yes

Are the conclusions drawn adequately supported by the results? Partly

Competing Interests: No competing interests were disclosed.

Reviewer Expertise: Vasculitis, SLE

We confirm that we have read this submission and believe that we have an appropriate level of expertise to confirm that it is of an acceptable scientific standard, however we have significant reservations, as outlined above.

Reviewer Report 03 March 2023

https://doi.org/10.5256/f1000research.120854.r163446

(c) 2023 Ramirez G. This is an open access peer review report distributed under the terms of the Creative Commons Attribution License, which permits unrestricted use, distribution, and reproduction in any medium, provided the original work is properly cited.

\section{Giuseppe A. Ramirez}

${ }^{1}$ Universita Vita Salute San Raffaele, Milan, Italy 
2 Unit of Immunology, Rheumatology, Allergy and Rare Diseases, Istituto di Ricovero e Cura a Carattere Scientifico San Raffaele, Milan, Italy

The authors performed an interesting study on the potential diagnostic role of T-cell immunosenescence markers in differentiating patients with SLE from healthy subjects and patients with active SLE from patients with quiescent disease. Specifically, they cross-sectionally assessed the frequency of CD4+ and CD8+ expressing CD57, CD45RA, CD45RO, KLRG1 or negative for CD28 in the peripheral blood as the fraction of total cells. In parallel, they tested the concentration of IFN gamma and IL2 as well as of antiDNA antibodies and complement. The authors conclude that T-cell senescence, especially on the CD8+ side identifies patients with active SLE increasing the diagnostic accuracy of common biomarkers.

The data are generally well presented and the topic is interesting. There are, however, several points needing further clarification

1. Clinical features. It is unclear whether the authors used LLDAS as defined by Franklyn et al. to define patients with active vs quiescent disease or whether they used a variant of this tool.

It is also important to highlight that a SLEDAI score of 4 can be easily and frequently achieved by active serology (that is ADNA and low complement) rather than with clinical features. Consequently, using ADNA and complement as reference biomarkers for estimating disease activity might be tautologic.

It is also unclear why one patient with inactive disease was taking cyclophosphamide. Indeed, if LLDAS criteria were used this patient would not be classified as an inactive subject.

Prednisone has a major impact on leukocyte biology. The authors should report prednisone doses besides the frequency of patients taking that drug and test for possible interactions with their immunophenotyping results.

2. CMV. CMV serology provides insufficient information on the potential role of CMV in affecting disease activity and immunosenescence. This should be at least discussed among the limitations of the study.

3. Data interpretation. There is insufficient discussion of previous evidence regarding the role and dynamics of T-cells in SLE, including immunosenescence (e.g. doi: 10.1111/cei.13577; 10.3390/ijms232213928; 10.1002/art.40180; 10.1002/art.24499.).

Furthermore, the authors assume that changes in the relative frequency of CD4+ and CD8+ subpopulations would mirror the systemic balance of these cells but leukocyte migration into inflamed tissues during active disease might also account for these phenomena (10.1136/ard.2009.124636).

They also assume that senescent T cells have a pathogenic role in SLE, although they can just represent an epiphenomenon.

The authors state that "this is the first study that described the role of several 
immunosenescence markers in predicting the active disease of SLE". Indeed, no predictive value can be inferred from the authors' data since there was no intraindividual or longitudinal assessment.

\section{References}

1. Lima G, Treviño-Tello F, Atisha-Fregoso Y, Llorente L, et al.: Exhausted T cells in systemic lupus erythematosus patients in long-standing remission.Clin Exp Immunol. 2021; 204 (3): 285-295

PubMed Abstract | Publisher Full Text

2. Lioulios G, Mitsoglou Z, Fylaktou A, Xochelli A, et al.: Exhausted but Not Senescent T Lymphocytes Predominate in Lupus Nephritis Patients.Int J Mol Sci. 2022; 23 (22). PubMed Abstract | Publisher Full Text

3. Kubo S, Nakayamada S, Yoshikawa M, Miyazaki Y, et al.: Peripheral Immunophenotyping Identifies Three Subgroups Based on T Cell Heterogeneity in Lupus Patients.Arthritis Rheumatol. 2017; 69 (10): 2029-2037 PubMed Abstract | Publisher Full Text

4. Yang J, Chu Y, Yang $X$, Gao D, et al.: Th17 and natural Treg cell population dynamics in systemic lupus erythematosus.Arthritis Rheum. 2009; 60 (5): 1472-83 PubMed Abstract | Publisher Full Text 5. Dolff S, Abdulahad WH, van Dijk MC, Limburg PC, et al.: Urinary T cells in active lupus nephritis show an effector memory phenotype.Ann Rheum Dis. 2010; 69 (11): 2034-41 PubMed Abstract I Publisher Full Text

Is the work clearly and accurately presented and does it cite the current literature? Partly

Is the study design appropriate and is the work technically sound? Partly

Are sufficient details of methods and analysis provided to allow replication by others? Partly

If applicable, is the statistical analysis and its interpretation appropriate? Yes

Are all the source data underlying the results available to ensure full reproducibility? Yes

Are the conclusions drawn adequately supported by the results? Partly

Competing Interests: No competing interests were disclosed.

Reviewer Expertise: systemic lupus erythematosus, autoimmune diseases, inflammation

I confirm that I have read this submission and believe that I have an appropriate level of expertise to state that I do not consider it to be of an acceptable scientific standard, for reasons outlined above. 
Reviewer Report 09 August 2022

https://doi.org/10.5256/f1000research.120854.r146599

(C) 2022 Chan T. This is an open access peer review report distributed under the terms of the Creative Commons Attribution License, which permits unrestricted use, distribution, and reproduction in any medium, provided the original work is properly cited.

\section{Tak Mao Chan}

Division of Nephrology, Department of Medicine, Queen Mary Hospital, The University of Hong Kong, Hong Kong, China

The authors presented the results from a cross-sectional study that investigated the relationship between peripheral blood $T$ cell senescence markers as determined by flow cytometry and disease activity in 61 SLE patients (43 active as defined by SLEDAI>4) and 60 healthy controls.

Questions and comments:

1. 20 active SLE patients had renal involvement, and 22 active SLE patients had mucocutaneous involvement. It would be of interest to assess the performance of the $T$ cell senescence markers in these subgroups.

2. Is the expression of senescence markers related to organ involvement in SLE?

3. The results require validation in longitudinal studies. Also, the results demonstrate an 'association' of senescence markers with disease activity, not 'predicting' the development of active disease.

4. For $C D 4 / C D 8$ ratio between inactive and active SLE patients $(0.7 \pm 0.2$ and $0.6 \pm 0.2$ respectively), the $P$ value of 0.026 seems a bit surprising.

5. Under Methods, first paragraph, on the justification for sample size quoting the investigators' previous results, please list the work by Kalim et al 2019 in full as a reference.

Is the work clearly and accurately presented and does it cite the current literature? Yes

Is the study design appropriate and is the work technically sound? Yes

Are sufficient details of methods and analysis provided to allow replication by others? Yes

If applicable, is the statistical analysis and its interpretation appropriate? Yes

Are all the source data underlying the results available to ensure full reproducibility? 
Yes

Are the conclusions drawn adequately supported by the results?

Yes

Competing Interests: No competing interests were disclosed.

Reviewer Expertise: lupus nephritis

I confirm that I have read this submission and believe that I have an appropriate level of expertise to confirm that it is of an acceptable scientific standard.

The benefits of publishing with F1000Research:

- Your article is published within days, with no editorial bias

- You can publish traditional articles, null/negative results, case reports, data notes and more

- The peer review process is transparent and collaborative

- Your article is indexed in PubMed after passing peer review

- Dedicated customer support at every stage

For pre-submission enquiries, contact research@f1000.com 